\section{ALSO OUT NOW}

\author{
A Ball, a Dog, and a Monkey: \\ 1957 - The Space Race Begins \\ by Michael D'Antonio \\ Simon \& Schuster
}

\section{Epic Rivalry: The Inside Story of the Soviet and American Space Race}

by Von Hardesty and Gene

Eisman

National Geographic

\author{
Space: The First 50 Years \\ by Patrick Moore \& \\ H. J. P. Arnold \\ Mitchell Beazley
}

Von Braun: Dreamer of Space, Engineer of War by Michael J. Neufeld Knopf

After Sputnik: 50 Years of the
Space Age
edited by Martin Collins
Smithsonian/HarperCollins

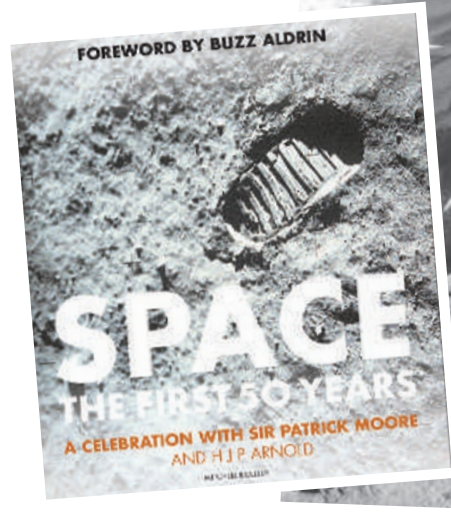
After Sputnik

50 Years of the Space Age

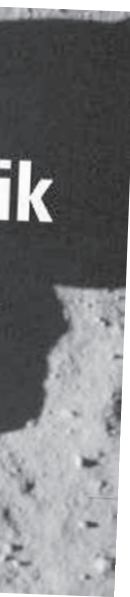

FILM

\title{
Earth's fearful travelling companion
}

\author{
The Fever of ' 57 \\ directed by David Hoffman \\ Available on DVD \\ In the Shadow of the Moon \\ directed by David Sington \\ On general release
}

\section{Giovanni F. Bignami \\ "Beep-Beep! Beep-Beep! Around the Earth it goes! Beep-Beep! Beep-Beep! And that's how science grows..." So warbles the long-forgotten Sputnik song over the end credits of The Fever of '57. This rigorous and affecting documen- tary feature captures the US public's wonder - and then fear - on discovering that the Soviets had launched an 83-kilogram} metal sphere over the world.

Named in poetic Russian style, Sputnik zemli means 'a travelling companion of the Earth'. Director David Hoffman uses rare archive footage, often from private collectors, to recount the drama of the launch in the context of the escalating cold war. He contrasts the awe of the man on the street for the majestic technological achievement with the political nightmare that began for the Eisenhower administration, already mired in civil-rights unrest.

Black-and-white images show worry etched into President Dwight Eisenhower's usually reassuring face. His embarrassment in being unable to answer press-conference questions calls to mind George W. Bush's demeanour on learning of the 9/11 attacks. Experts, including Edward Teller, immediately grasped the implications of getting cargo of this size into orbit: international ballistic missiles. The United States, the proclaimed science capital of the world, was humiliated.

Hoffman exhumes typical Khrushchev-era propaganda - tastefully shot, with a few too many Lenin portraits. Anti-American footage contrasts US prisons and hungry queues with

food being tipped into the sea and the rich having their pets professionally manicured.

Political tensions heightened a month after Sputnik, when Laika the dog went into orbit in a full-bodied spaceship. US news coverage, now in colour, shows animal-lovers protesting.

Eisenhower was loath to seek help from the army, fearing that military involvement would stimulate an arms race. The US Army rocket programme was led by Wernher von Braun, the designer of Germany's V-2, which had bombed London and other cities 15 years earlier. Finally, von Braun's rocket launched the first US satellite, Explorer 1, on 31 January 1958. James Van Allen put Geiger counters in it and so discovered the radiation belts around

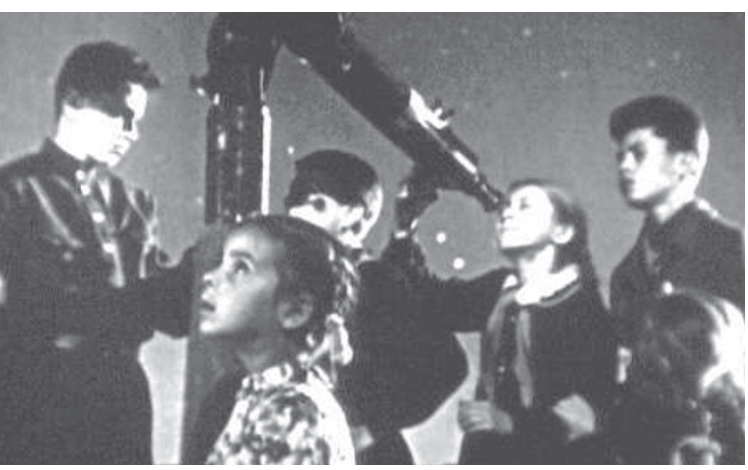

Soviet awe of Sputnik contrasted with US fear and political unrest.

test was conducted every three days, including the largest $\mathrm{H}$-bomb ever detonated above ground. And both sides were developing civil defence programmes.

Meanwhile, headlines were screaming 'Soviets could claim the Moon'. In 1959 the USSR launched three Moon probes. One missed, another crash-landed on it (carrying a red flag, they say); the third sent us the first, breathtaking, image of the hidden side of the Moon.

David Sington's In the Shadow of the Moon picks up where The Fever of '57 leaves off. This cinéma-vérité history of NASA's Apollo programme splices remastered original footage and original interviews with ten Apollo astronauts, presented by Ron Howard, director of the 1995 film Apollo 13.

As in the 1983 movie The Right Stuff, we learn what it took in the pioneering days of manned space missions to become a NASA astronaut. "An unshakable belief in your own infallibility," says one interviewee. The astronauts were all military pilots; more than one felt guilty about training for glamour and fame while their comrades were dying in the Vietnam War.

Notable for his absence is Neil Armstrong. Shown here is the eerie speech by President Richard Nixon, recorded for use in the event that the one-shot ascent

Earth that now carry his name.

Soon afterwards, Eisenhower created NASA as a civilian space agency. Reluctantly, von Braun joined, developing the Saturn V rocket that eventually brought man to the Moon. In an extraordinary public-relations coup, Eisenhower plotted the Scope mission with the nascent NASA in secret - not even Congress knew. The satellite bore his 1958 Christmas message to the world.

The US public was still worried. The Soviets were pushing farther into space. Both sides were developing nuclear weapons, as Eisenhower had predicted. During 1958, one nuclear module motor failed to ignite, leaving Armstrong and Buzz Aldrin to die on the Moon.

"We have yet to return to the Moon," says Sington at the end of his Sundance awardwinning mosaic. Today's white manes and bald pates - yesterday's young men - are the only people to have hidden the whole Earth behind their thumb. NASA is working on "Apollo on steroids", with infinitely better technology than 40 years ago. The distance to the Moon, within a few centimetres, remains the same.

Giovanni F. Bignami is president of the Italian Space Agency and is at the Institute for Advance Study, 27100 Pavia, Italy. 